\title{
Nomimicin, a new spirotetronate-class polyketide from an actinomycete of the genus Actinomadura
}

\author{
Yasuhiro Igarashi ${ }^{1}$, Takako Iida ${ }^{1}$, Naoya Oku ${ }^{1}$, Hiroyuki Watanabe ${ }^{2}$, Kazuo Furihata ${ }^{3}$ and Koji Miyanouchi ${ }^{4}$ \\ Nomimicin (1), a new spirotetronate-class polyketide, was isolated from the culture broth of an actinomycete of the genus \\ Actinomadura. Its structure was established by spectroscopic methods, and the absolute configuration was determined by a \\ combination of NOESY experiment, J-based configuration analysis and the modified Mosher method. Nomimicin (1) showed \\ antimicrobial activity against Micrococcus luteus, Candida albincans and Kluyveromyces fragilis.
}

The Journal of Antibiotics (2012) 65, 355-359; doi:10.1038/ja.2012.30; published online 25 April 2012

Keywords: Actinomadura; polyketide; spirotetronate

\begin{abstract}
INTRODUCTION
Microbial secondary metabolites have been the most productive source of small molecules for the development of drugs. ${ }^{1}$ Almost a half of the known microbial bioactive compounds are derived from actinomycetes, and specifically Streptomyces accounts for more than $70 \%$ of the actinomycete-derived metabolites. ${ }^{2}$ Among the nonStreptomyces species, Micromonospora is the leading producer of secondary metabolites, including polyketides, peptides and glycosides, whereas Actinomadura is known as a producer of chemically and biologically unique polyketides such as antitumor enediynes, ${ }^{3}$ mannose-binding quinone glycosides with antifungal and anti-HIV activities ${ }^{4}$ and anticoccidial polyethers, ${ }^{5}$ accounting for up to 350 compounds reported as of $2005 .^{2}$ During our continuing investigation on the metabolites from actinomycetes of nonStreptomyces group, ${ }^{6,7}$ a new spirotetronate antibiotic of polyketide origin, nomimicin (1, Figure 1), was isolated from the culture extract of Actinomadura sp. TP-A0878. In this paper, we describe the isolation, structural determination and biological properties of 1 .
\end{abstract}

\section{RESULTS AND DISCUSSION}

The producing strain TP-A0878 was isolated from a compost sample collected at Nomi, Ishikawa, Japan, and identified as a member of Actinomadura on the basis of 16S rRNA gene sequence. This strain was cultured in $\mathrm{A}-3 \mathrm{M}$ medium at $30^{\circ} \mathrm{C}$ for 6 days, and the whole culture broth was extracted with 1-butanol. The extract was consecutively fractionated by normal- and reversed-phase column chromatographies, followed by HPLC purification on a $\mathrm{C}_{18}$ column, to yield nomimicin (1) as an optically active, amorphous solid $\left([\alpha]_{\mathrm{D}}-94, \mathrm{CHCl}_{3}\right)$. Compound $\mathbf{1}$ gave a pseudomolecular ion at $m / z 519.2726[\mathrm{M}+\mathrm{Na}]^{+}$in a HR-ESI time-of-flight (TOF) MS measurement, suggesting a molecular formula of $\mathrm{C}_{30} \mathrm{H}_{40} \mathrm{O}_{6}$, which was subsequently corroborated by the NMR data. The IR spectrum indicated the presence of hydroxyl $\left(3397 \mathrm{~cm}^{-1}\right)$ and carbonyl $\left(1749 \mathrm{~cm}^{-1}\right)$ functionalities. Analysis of ${ }^{1} \mathrm{H}$ and ${ }^{13} \mathrm{C} \mathrm{NMR}$, and HSQC data established three oxygenated quaternary $s p^{2}$ carbons, seven $s p^{2}$ carbons (five are proton-bearing), three quaternary $s p^{3}$ carbons (one is oxygen-bearing), seven $s p^{3}$ methines (two are oxygen-bearing), five $s p^{3}$ methylenes and five methyl groups (Table 1). The UV spectrum of $\mathbf{1}$ was closely similar to that of maklamicin $^{7}$ (Figure 1), a spirotetronate polyketide that we recently discovered from a Micromonospora strain, suggesting the presence of a tetronic acid functionality in this molecule. This was supported by the ${ }^{13} \mathrm{C}$ chemical shifts of the carbons $\mathrm{C}-1\left(\delta_{\mathrm{C}} 167.0\right), \mathrm{C}-2\left(\delta_{\mathrm{C}} 107.2\right), \mathrm{C}-3$ $\left(\delta_{\mathrm{C}} 200.3\right)$ and C-24 $\left(\delta_{\mathrm{C}} 204.5\right)$ that closely matched those reported for this structure in maklamicin. As three double bonds and a tetronic acid unit that contains three double bonds and one ring accounted 7 of the 11 double-bond equivalents, 1 must possess four more rings to satisfy the molecular formula.

Interpretation of the COSY and HSQC spectra provided six fragments (indicated by bold lines, Figure 2), and the linkage among these fragments was established by analysis of $\mathrm{HMBC}$ correlations. A secondary methyl fragment C-8/C-26 and two large fragments C-7/C6/C-5/C-10/C-9 and C-11-C-17 were joined to form an oxygenated cyclohexane substructure, based on $\mathrm{HMBC}$ correlations from $\mathrm{H}_{3}-26$ to C-7 and C-9, H-11 to C-5 and C-9, and H-9 to C-11. Furthermore, a series of long-range correlations from a singlet methyl proton resonance $\mathrm{H}_{3}-25$ to $\mathrm{C}-3, \mathrm{C}-4, \mathrm{C}-5$ and $\mathrm{C}-13$ fused an additional ring to the cyclohexane ring. Accordingly, a $\Delta^{1}$-octalin framework with an olefinic extension (C-14 to C-17) and a carbonyl functionality from the tetronic acid unit $(\mathrm{C}-3)$ were established to be present in the bottom half of the molecule. The E-geometry of the olefinic extension was deduced from a large vicinal coupling constant between $\mathrm{H}-15$ and

${ }^{1}$ Biotechnology Research Center, Toyama Prefectural University, Toyama, Japan; ${ }^{2}$ Agilent Technologies Japan Ltd., Tokyo, Japan; ${ }^{3}$ Department of Applied Biological Chemistry, Graduate School of Agricultural and Life Sciences, The University of Tokyo, Tokyo, Japan and ${ }^{4}$ Bio Technical Research Industry Co. Ltd, Nomi, Japan Correspondence: Professor Dr Y Igarashi, Biotechnology Research Center, Toyama Prefectural University, 5180 Kurokawa, Imizu, Toyama 939-0398, Japan. E-mail: yas@pu-toyama.ac.jp

Received 21 December 2011; revised 25 January 2012; accepted 8 February 2012; published online 25 April 2012 
$\mathrm{H}-16(15.3 \mathrm{~Hz})$. The remaining fragments C-21/C-22, C-29/C-30 and C-19/C-20/C-28 were established by COSY correlations, and were assembled by $\mathrm{HMBC}$ correlations from $\mathrm{H}_{3}-28$ to C-19, C-20 and
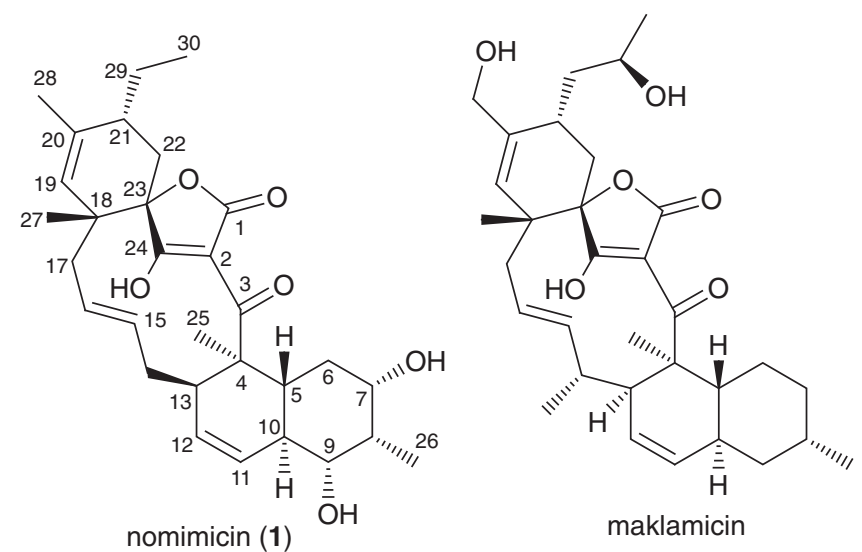

Figure 1 Structures of nomimicin (1) and maklamicin.
C-21, H-30 to C-21, and H-29 to C-20 and C-22 into the upper half of the cyclohexene unit in the top half of the molecule. Finally, a set of HMBC correlations from $\mathrm{H}_{3}-27$ to $\mathrm{C}-17, \mathrm{C}-18, \mathrm{C}-19$ and $\mathrm{C}-23$ assigned an oxygenated spirocarbon (C-23) and a quaternary carbon $\mathrm{C}-18$ to be placed in the lower half of the cyclohexene ring, and at the same time, as a juncture to the tetronic acid moiety and to the terminus of the octalin extension, respectively. The spiro connection between the cyclohexene and tetronic acid units was also supported by an HMBC correlation from $\mathrm{H}_{2}-22$ to $\mathrm{C}-24$, and thus a characteristic pentacycle-condensed spirotetronate structure was assigned for 1 (Figure 2).

The relative configuration was elucidated by NOESY experiments and $J$-based configuration analysis (Figures 3 and 4). NOEs between $\mathrm{H}-5, \mathrm{H}-7$ and $\mathrm{H}-9$, and large scalar couplings $\left({ }^{3} \mathrm{~J}_{\mathrm{HH}}>10 \mathrm{~Hz}\right)$ shown by $\mathrm{H}-5 / \mathrm{H}-6 \alpha, \mathrm{H}-6 \alpha / \mathrm{H}-7$ and $\mathrm{H}-5 / \mathrm{H}-10$ provided the 1,3 -diaxial relationships between $\mathrm{H}-5, \mathrm{H}-7$ and $\mathrm{H}-9$, and a trans ring fusion in the octalin unit. The axial orientation of the methyl group at C-8 was confirmed by an NOE between $\mathrm{H}_{3}-26$ and $\mathrm{H}-10$. NOEs between $\mathrm{H}-10$ and $\mathrm{H}_{3}-25$, and between $\mathrm{H}_{3}-25$ and $\mathrm{H}-13$ placed the $\mathrm{H}_{3}-25$ methyl and $\mathrm{H}-13$ on the same side of the octalin ring, with respect to the

Table $1{ }^{1} \mathrm{H}$ and ${ }^{13} \mathrm{C}$ NMR data for nomimicin (1) in $\mathrm{CDCl}_{3}$

\begin{tabular}{|c|c|c|c|c|c|}
\hline Position & $\delta_{C}{ }^{a}$ & $\delta_{H}$ mult $(J \text { in } H z)^{\mathrm{b}}$ & $H M B C^{\mathrm{b}, \mathrm{c}}$ & $\cos Y^{b}$ & NOESYb \\
\hline 1 & 167.0, qC & & & & \\
\hline 2 & 107.2, qC & & & & \\
\hline 3 & 200.3, qC & & & & \\
\hline 4 & $49.4, q C$ & & & & \\
\hline 5 & $34.9, \mathrm{CH}$ & 1.55, br.dd $(11.3,11.0)$ & $4,6,7,9,25$ & $6 \alpha, 10$ & 7,9 \\
\hline $6 \alpha$ & $30.7, \mathrm{CH}_{2}$ & 1.32, ddd $(11.7,11.6,11.3)$ & $4,5,7,10$ & $5,6 \beta, 7$ & $6 \beta$ \\
\hline $6 \beta$ & & 2.18, br.d (11.7) & $4,5,7,8,10$ & $6 \alpha, 7$ & $6 \alpha, 7$ \\
\hline 7 & $71.1, \mathrm{CH}$ & 3.96, ddd $(11.6,4.6,4.6)$ & $5,6,8,9,26$ & $6 \alpha, 6 \beta$ & $5,6 \beta, 8,9$ \\
\hline 8 & $41.5, \mathrm{CH}$ & $2.45, \mathrm{~m}$ & $6,7,9,10,26$ & 26 & $7,9,26$ \\
\hline 9 & $74.0, \mathrm{CH}$ & 3.45, dd $(10.7,4.8)$ & $5,8,10,11,26$ & 10 & $5,7,8$ \\
\hline 10 & $36.9, \mathrm{CH}$ & $1.97, \mathrm{~m}$ & 9 & 5,9 & $11,25,26$ \\
\hline 11 & 122.7, $\mathrm{CH}$ & $5.81, d(10.0)$ & $5,9,13$ & 12 & 10 \\
\hline 12 & $131.2, \mathrm{CH}$ & 5.60, ddd $(10.0,5.1,2.5)$ & $4,10,13$ & 11,13 & $13,14 a$ \\
\hline 13 & $37.7, \mathrm{CH}$ & 2.82, br.dd $(5.1,5.1)$ & $4,11,12,14,15,25$ & $12,14 b$ & $12,15,25$ \\
\hline $14 a$ & $36.4, \mathrm{CH}_{2}$ & $1.99, \mathrm{~m}$ & 15 & $14 \mathrm{~b}$ & 12,15 \\
\hline $14 b$ & & $1.74, \mathrm{~m}$ & $4,13,15,16$ & $13,14 a, 15$ & 16 \\
\hline 15 & $136.8, \mathrm{CH}$ & 5.54, dddd $(15.3,10.7,2.4,2.4)$ & 14,17 & $14 b, 16$ & $13,14 a, 17 b$ \\
\hline 16 & $123.1, \mathrm{CH}$ & 5.04, dddd $(15.3,11.5,2.4,2.4)$ & 14,17 & $15,17 b$ & $14 b, 17 a, 27$ \\
\hline $17 a$ & $42.6, \mathrm{CH}_{2}$ & $1.93, \mathrm{~m}$ & $15,16,18,19,27$ & $17 \mathrm{~b}$ & $16,17 b, 19$ \\
\hline $17 b$ & & 2.40, dd $(13.8,11.5)$ & $15,16,23$ & $16,17 a$ & $15,17 a$ \\
\hline 18 & $39.3, \mathrm{C}$ & & & & \\
\hline 19 & 129.1, CH & 4.97 & $17,18,23,28$ & & $17 a, 27,28$ \\
\hline 20 & 133.7, C & & & & \\
\hline 21 & $39.0, \mathrm{CH}$ & $1.96, \mathrm{~m}$ & 30 & $22 \beta$ & $22 \beta$ \\
\hline $22 \alpha$ & $29.4, \mathrm{CH}_{2}$ & $1.73, \mathrm{~m}$ & $21,23,24,29$ & $22 \beta$ & $22 \beta$ \\
\hline $22 \beta$ & & $2.26, \mathrm{dd}(14.8,7.7)$ & $18,21,23,24,29$ & $21,22 \alpha$ & $21,22 \alpha, 27$ \\
\hline 23 & $86.2, \mathrm{qC}$ & & & & \\
\hline 24 & $204.5, q C$ & & & & \\
\hline 25 & $16.1, \mathrm{CH}_{3}$ & $1.61, \mathrm{~s}$ & $3,4,5,13$ & & 10,13 \\
\hline 26 & $5.5, \mathrm{CH}_{3}$ & $0.99, \mathrm{~d}(7.0)$ & $7,8,9$ & & 8,10 \\
\hline 27 & $23.8, \mathrm{CH}_{3}$ & $1.22, \mathrm{~s}$ & $17,18,19,23$ & & $16,19,22 \beta$ \\
\hline 28 & $22.1, \mathrm{CH}_{3}$ & $1.73, \mathrm{~s}$ & $19,20,21$ & & 19 \\
\hline \multirow[t]{2}{*}{29} & $25.1, \mathrm{CH}_{2}$ & $1.60, \mathrm{~m}$ & 22 & 30 & \\
\hline & & $1.72, \mathrm{~m}$ & $20,22,30$ & 30 & \\
\hline 30 & $12.9, \mathrm{CH}_{3}$ & $0.91, \mathrm{t}(7.4)$ & 21,29 & $29 a, 29 b$ & \\
\hline
\end{tabular}




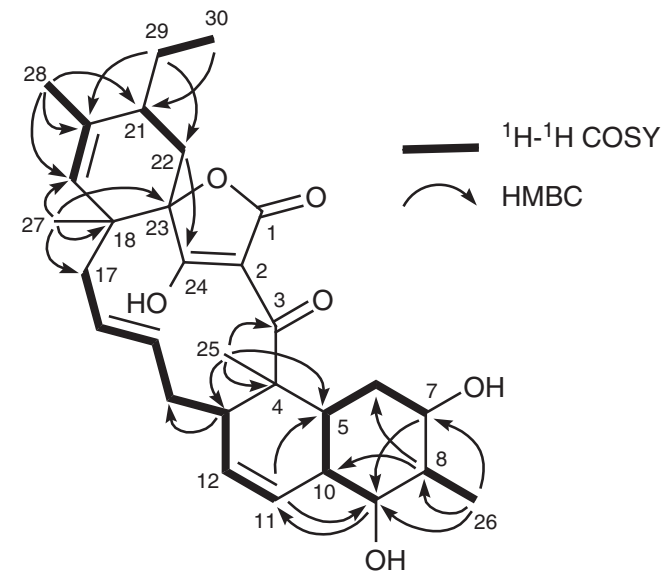

Figure $2{ }^{1} \mathrm{H}-{ }^{1} \mathrm{H}$ COSY and selected $\mathrm{HMBC}$ correlations for $\mathbf{1}$.

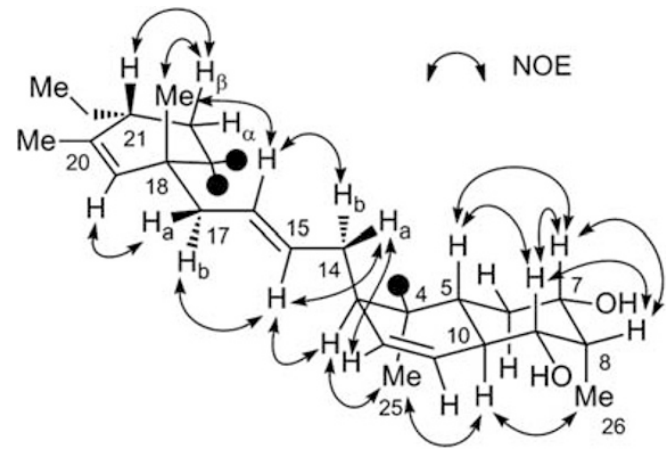

Figure 3 Conformation and configuration of $\Delta^{1}$-octalin and cyclohexene moieties of 1 determined by NOESY data and J-based analysis.

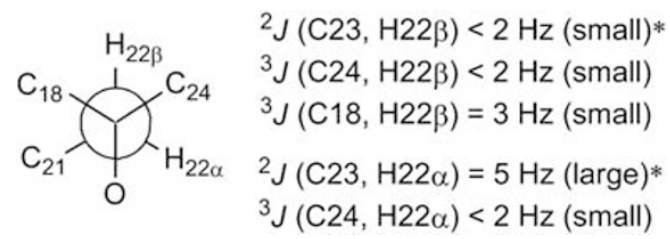

Figure 4 Configuration at $\mathrm{C}-23$ of $\mathbf{1}$ determined on the basis of ${ }^{2} J_{\mathrm{CH}}$ and ${ }^{3} J_{\mathrm{CH}}$ values. *Absolute values.

axial $\mathrm{H}-10$ proton. A series of NOESY correlations for $\mathrm{H}-13 / \mathrm{H}-15$, $\mathrm{H}-15 / \mathrm{H}-17 \mathrm{~b}, \mathrm{H}-17 \mathrm{a} / \mathrm{H}-19, \mathrm{H}-14 \mathrm{~b} / \mathrm{H}-16$ and $\mathrm{H}-16 / \mathrm{H}_{3}-27$, established a zigzag conformation of the $\mathrm{C}-13$ to $\mathrm{C}-18$ chain, and the configuration at C-18 relative to C-13. Furthermore, NOEs between $\mathrm{H}-21$ and $\mathrm{H}-22 \beta$, and between $\mathrm{H}-22 \beta$ and $\mathrm{H}_{3}-27$ established that these protons were located on the same side of the cyclohexene ring (Figure 3). Finally, the configuration at the spirocarbon C-23 was determined using the $J$-based configuration analysis. ${ }^{8}$ Heteronuclear long-range coupling constants ${ }^{2} J_{\mathrm{CH}}$ and ${ }^{3} J_{\mathrm{CH}}$ were determined by $J$-resolved HMBC experiments. ${ }^{9,10} \mathrm{~J}$-Resolved HMBC spectra were measured on a Varian INOVA-500 spectrometer at $20^{\circ} \mathrm{C}$ using a microtube (Shigemi Inc., Tokyo, Japan) in $\mathrm{CDCl}_{3}$ (10 mg of 1 in $0.25 \mathrm{ml}$ ). In the $J$-resolved HMBC spectra, ${ }^{2} J_{\mathrm{CH}}$ and ${ }^{3} J_{\mathrm{CH}}$ values are obtained as absolute values. The small coupling constant between $\mathrm{H}-22 \beta$ and C-23 $\left({ }^{2} J_{\mathrm{CH}}<2 \mathrm{~Hz}\right)$, and the large coupling constant between $\mathrm{H}-22 \alpha$ and $\mathrm{C}-23\left({ }^{2} J_{\mathrm{CH}}=5 \mathrm{~Hz}\right)$ suggested the anti-relationship of $\mathrm{H}-22 \beta$ and the oxygen atom at C-23 (Figure 4).

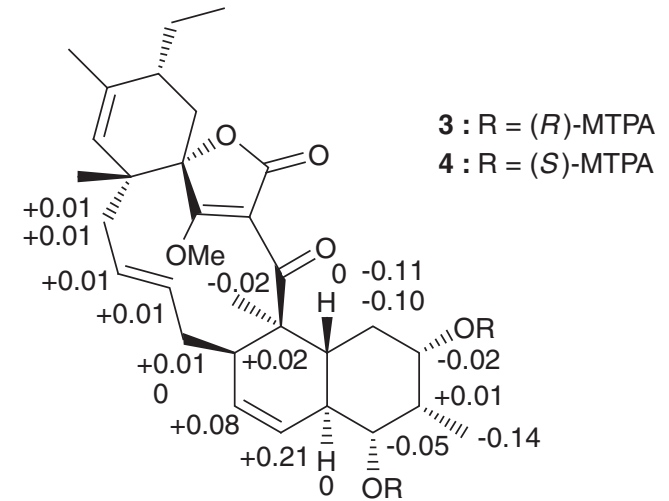

Figure $5 \Delta \delta_{\mathrm{S}-\mathrm{R}}$ values for bisMTPA esters (3 and $\mathbf{4}$ ) of 2 .

The absolute stereochemistry was determined by applying the modified Mosher method ${ }^{11}$ to the secondary hydroxyl groups at C-7 and C-9, both of which were in equatorial orientation. After methylation of the enolic hydroxyl group at C-24 with $\mathrm{TMSCHN}_{2}$ in $\mathrm{CHCl}_{3} / \mathrm{MeOH}$, the methylated product 2 was reacted with $(S)$ and $(R)$-MTPA ( $\alpha$-methoxy- $\alpha$-trifluoromethylphenylacetyl) chloride, yielding bis- $(R)$ - and (S)-MTPA esters (3 and 4), respectively. Calculation of the $\Delta \delta_{\mathrm{H}}(S-R)$ values identified $\mathrm{H}-11$ to $\mathrm{H}_{2}-17$ to have positive signs, whereas $\mathrm{H}_{2}-6$ and $\mathrm{H}_{3}-25$ negative signs (Figure 5). These data allowed assignment of both the absolute configurations at C-7 and C-9 as R. Although signs were mixed for the protons flanked by the MTPA ester groups, the sign distribution pattern is in good accordance with that reported for bisMTPA derivatives of cyclohexane-1,3-diols. ${ }^{12}$ The deduced absolute configuration was identical with that known for this antibiotic family. ${ }^{13,14}$

Spirotetronates represented by kijanimicin ${ }^{15}$ feature a trans- $\Delta^{1}$ octalin unit and a tetronic acid moiety spiro-linked with a cyclohexene ring. To date, over 50 related metabolites have been discovered from actinomycetes. Their structural variations are largely derived from the glycosylation pattern and the length of the carbon chain connecting the octalin and the cyclohexene units. Maklamicin is the first example to have the shortest four-carbon linker, and nomimicin (1) is a new member of this class.

Nomimicin (1) showed antimicrobial activities against Micrococcus luteus, Candida albicans and Kluyveromyces fragilis with MIC values of $6.3,12.5$ and $12.5 \mu \mathrm{g} \mathrm{ml}^{-1}$, respectively, whereas it was inactive against Escherichia coli. In contrast, maklamicin is not active against these yeasts, suggesting the effect of the hydroxylation pattern on antifungal activities. Compound $\mathbf{1}$ displayed weak cytotoxicity against human cervical cancer cells HeLa and human breast cancer cells MCF7, with $\mathrm{IC}_{50}$ values of 74 and $59 \mu \mathrm{M}$, respectively.

\section{EXPERIMENTAL PROCEDURES}

\section{General experimental procedures}

Optical rotations were measured using a JASCO DIP-3000 polarimeter (JASCO Corporation, Tokyo, Japan). UV spectrum was recorded on a Hitachi U-3210 spectrophotometer (Hitachi, Tokyo, Japan). IR spectrum was measured on a Perkin Elmer Spectrum 100 (Perkin-Elmer, Fremont, CA, USA). ${ }^{13} \mathrm{C}$ NMR spectra were measured on a Bruker AVANCE 400 spectrometer, and ${ }^{1} \mathrm{H}$ and 2D NMR spectra were obtained on a Bruker AVANCE 500 spectrometer (Bruker, Rheinstetten, Germany). Chemical shifts were referenced to residual solvent signals $\left(\delta_{\mathrm{H}} 7.26, \delta_{\mathrm{C}} 77.0\right)$. $J$-Resolved HMBC experiments were performed on a Varian INOVA-500 spectrometer (Varian Inc., Palo Alto, CA, USA). HRESITOFMS were recorded on a Bruker microTOF focus. Silica Gel 60 (Kanto 
Chemical Co., Inc., Tokyo, Japan; 63-210 mesh) and Silica Gel 60-C18 (Nacalai Tesque, Kyoto, Japan; 250-350 mesh) were used for silica gel and octa decyl silica (ODS) column chromatographies, respectively. HPLC separation was performed using an $\mathrm{XTerra}^{\mathrm{RP}_{18}}$ (Waters Corporation, Milford, MA, USA; $7 \mu \mathrm{m}, 19 \times 300 \mathrm{~mm})$ with a photodiode array detector.

\section{Producing microorganism}

Strain TP-A0878 was isolated from a compost sample collected at Nomi, Ishikawa, Japan, in 2007. The strain was identified as a member of the genus Actinomadura on the basis of $100 \%$ identity of $16 \mathrm{~S}$ rRNA gene sequence (1462 nucleotides; DDBJ accession number AB488798) with Actinomadura sp. TFS 455 (accession number EF2120220).

\section{Fermentation}

Strain TP-A0878 cultured on a Bn-2 slant (soluble starch $0.5 \%$, glucose $0.5 \%$, meat extract (Kyokuto Pharmaceutical Industrial Co., Ltd., Tokyo, Japan) $0.1 \%$, yeast extract (Difco Laboratories, Becton, Dickinson and Company, Sparks, MD, USA) $0.1 \%$, NZ-case (Wako Chemicals USA, Inc., Richmond, VA, USA) $0.2 \%, \mathrm{NaCl} 0.2 \%, \mathrm{CaCO}_{3} 0.1 \%$, agar $1.5 \%$ ) was inoculated into $500-\mathrm{ml}$ K-1 flasks, each containing $100 \mathrm{ml}$ of V-22 seed medium consisting of soluble starch $1 \%$, glucose $0.5 \%$, NZ-case (Wako Chemicals USA, Inc.) $0.3 \%$, yeast extract (Difco Laboratories) $0.2 \%$, tryptone (Difco Laboratories) $0.5 \%$, $\mathrm{K}_{2} \mathrm{HPO}_{4} 0.1 \%, \mathrm{MgSO}_{4} \cdot 7 \mathrm{H}_{2} \mathrm{O} 0.05 \%$ and $\mathrm{CaCO}_{3} 0.3 \%$ (pH 7.0). The flasks were placed on a rotary shaker $\left(200\right.$ r.p.m.) at $30^{\circ} \mathrm{C}$ for 4 days. The seed culture $(3 \mathrm{ml})$ was transferred into $500-\mathrm{ml} \mathrm{K}-1$ flasks, each containing $100 \mathrm{ml}$ of A-3M production medium consisting of glucose $0.5 \%$, glycerol $2 \%$, soluble starch 2\%, Pharmamedia (Traders Protein, Lubbock, TX, USA) $1.5 \%$, yeast extract $0.3 \%$ and Diaion HP-20 (Mitsubishi Chemical Co., Tokyo, Japan) $1 \%$. The $\mathrm{pH}$ of the medium was adjusted to 7.0 before sterilization. The inoculated flasks were placed on a rotary shaker $\left(200\right.$ r.p.m.) at $30^{\circ} \mathrm{C}$ for 6 days.

\section{Extraction and isolation}

At the end of the fermentation period, $100 \mathrm{ml}$ of 1-butanol were added to each flask and they were allowed to shake for $1 \mathrm{~h}$. The mixture was centrifuged at 6000 r.p.m. for $10 \mathrm{~min}$, and the organic layer was separated from the aqueous layer containing the mycelium. Evaporation of the solvent gave $3.0 \mathrm{~g}$ of the crude extract from 2-l culture. This was subjected to silica gel column chromatography with a stepwise gradient of $\mathrm{CHCl}_{3} / \mathrm{MeOH}(1: 0,20: 1,10: 1$, 4:1, 2:1, $1: 1$ and $0: 1 \mathrm{v} / \mathrm{v})$. Fractions $5(2: 1)$ and $6(1: 1)$ were concentrated to provide $0.47 \mathrm{~g}$ of a brown solid, which was further purified by reversed-phase ODS column chromatography with a gradient of $\mathrm{MeCN} / 0.15 \% \mathrm{KH}_{2} \mathrm{PO}_{4}$ buffer $(\mathrm{pH} 3.5 ; 2: 8,3: 7,4: 6,5: 5,6: 4,7: 3$ and 8:2 v/v). Fraction 6 (7:3) was evaporated to an aqueous solution, which was extracted with EtOAc. The organic layer was dried over anhydrous $\mathrm{Na}_{2} \mathrm{SO}_{4}$, filtered and concentrated to give a pale yellow solid $(90 \mathrm{mg})$. Final purification was achieved by repeated preparative HPLC with $\mathrm{MeCN} / 0.1 \% \mathrm{HCO}_{2} \mathrm{H}$ (MeCN concentration: $50 \%$ for $0-8 \mathrm{~min} ; 50-80 \%$ for $8-42 \mathrm{~min} ; 14 \mathrm{ml} \mathrm{min}^{-1}$; UV detection at $254 \mathrm{~nm}$ ), followed by evaporation and extraction with EtOAc, to yield nomimicin (1, $\left.19 \mathrm{mg}, t_{\mathrm{R}} 22.5 \mathrm{~min}\right)$.

\section{Nomimicin (1)}

Colorless amorphous solid; $[\alpha]^{23}{ }_{\mathrm{D}}-94\left(c 0.10, \mathrm{CHCl}_{3}\right) ; \mathrm{UV}(\mathrm{MeOH}) \lambda_{\max }(\log$ ع) 250 (3.97), $293(3.89) \mathrm{nm}$; IR (attenuated total reflection) $v_{\max } 3397$, $1749 \mathrm{~cm}^{-1}$; ${ }^{1} \mathrm{H}$ and ${ }^{13} \mathrm{C}$ NMR data, see Table 1; HR-ESITOFMS $[\mathrm{M}+\mathrm{Na}]^{+}$ 519.2726 (calcd for $\mathrm{C}_{30} \mathrm{H}_{40} \mathrm{O}_{6} \mathrm{Na}, 519.2717$ ).

\section{Methylation of 1 to yield 2}

24-O-Methyl ether of $\mathbf{1}(\mathbf{2})$ : To a solution of $\mathbf{1}(5.0 \mathrm{mg}, 0.010 \mathrm{mmol})$ in $\mathrm{CHCl}_{3} /$ $\mathrm{MeOH}(0.25 \mathrm{ml}$ each $)$ was added a solution of $\mathrm{TMSCHN}_{2}$ in $\mathrm{Et}_{2} \mathrm{O}(2.0 \mathrm{M}$, $0.25 \mathrm{ml}, 0.50 \mathrm{mmol}$ ) at room temperature. After stirring for $15 \mathrm{~min}$, the reaction mixture was concentrated to dryness. The residue was purified on a silica-gel column chromatography (hexane/EtOAc $=20: 1-1: 1$ ) to give 2 $(3.5 \mathrm{mg})$ in $60 \%$ yield: colorless amorphous solid; $[\alpha]^{25} \mathrm{D}-52\left(c 0.50, \mathrm{CHCl}_{3}\right)$; ${ }^{1} \mathrm{H}$ NMR $\left(500 \mathrm{MHz}, \mathrm{CDCl}_{3}\right) \delta 0.91(3 \mathrm{H}, \mathrm{t}, J=7.6 \mathrm{~Hz}, \mathrm{H}-30), 0.96(3 \mathrm{H}, \mathrm{d}$, $J=7.0 \mathrm{~Hz}, \mathrm{H}-26), 1.04(3 \mathrm{H}, \mathrm{s}, \mathrm{H}-27), 1.20(1 \mathrm{H}, \mathrm{ddd}, J=11.9,11.9,11.7 \mathrm{~Hz}$,

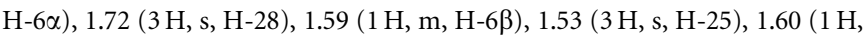

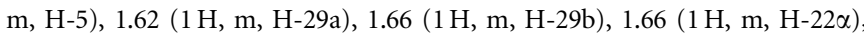
$1.84(1 \mathrm{H}, \mathrm{m}, \mathrm{H}-17 \mathrm{a}), 1.85$ (2 H, m, H-14), 1.88 (1 H, m, H-21), 1.91 (1 H, m, H-10), 2.18 ( $1 \mathrm{H}$, dd, $J=14.6,7.1 \mathrm{~Hz}, \mathrm{H}-22 \beta), 2.38$ ( $1 \mathrm{H}, \mathrm{m}, \mathrm{H}-8), 2.40(1 \mathrm{H}$ m, H-17b), 2.87 ( $1 \mathrm{H}$, br.dd, $J=5.0,5.0 \mathrm{~Hz}, \mathrm{H}-13), 3.43(1 \mathrm{H}, \mathrm{dd}, J=10.7$, $4.7 \mathrm{~Hz}, \mathrm{H}-9), 3.95$ (1 H, ddd, $J=11.7,4.3,4.3 \mathrm{~Hz}, \mathrm{H}-7), 4.07$ (3 H, s, $24-$ $\left.\mathrm{OCH}_{3}\right), 4.86(1 \mathrm{H}, \mathrm{s}, \mathrm{H}-19), 5.02(1 \mathrm{H}, \mathrm{dd}, J=15.1,11.4 \mathrm{~Hz}, \mathrm{H}-16), 5.30(1 \mathrm{H}$, dddd, $J=15.1,10.7,2.1,2.1 \mathrm{~Hz}, \mathrm{H}-15), 5.57(1 \mathrm{H}, \mathrm{ddd}, J=10.0,5.0,2.4 \mathrm{~Hz}$, $\mathrm{H}-12), 5.81(1 \mathrm{H}, \mathrm{d}, J=10.0 \mathrm{~Hz}, \mathrm{H}-11) ;{ }^{13} \mathrm{C} \mathrm{NMR}\left(100 \mathrm{MHz}, \mathrm{CDCl}_{3}\right) \delta 5.4(\mathrm{C}-$ 26), 13.0 (C-30), 15.5 (C-25), 22.2 (C-28), 23.7 (C-27), 24.8 (C-29), 29.6 (C6), 29.7 (C-22), 35.4 (C-5), 35.9 (C-14), 36.4 (C-10), 37.6 (C-13), 39.2 (C-21), 39.3 (C-18), 41.8 (C-8), 43.6 (C-17), $51.6(\mathrm{C}-4), 65.8\left(24-\mathrm{OCH}_{3}\right), 71.0(\mathrm{C}-7)$, 74.1 (C-9), 86.0 (C-23), 111.9 (C-2), 123.4 (C-11), 126.9 (C-16), 129.7 (C-19), 131.4 (C-15), 131.7 (C-12), 133.7 (C-20), 168.2 (C-1), 193.7 (C-24), 196.6 (C3); HR-ESITOFMS $[\mathrm{M}+\mathrm{Na}]^{+} 533.2865$ (calcd for $\mathrm{C}_{31} \mathrm{H}_{42} \mathrm{O}_{6} \mathrm{Na}, 533.2874$ ).

\section{Bis-(R)-MTPA ester of $2(3)$}

(S)-MTPA chloride $(5.0 \mu \mathrm{l}, 27 \mu \mathrm{mol})$ was added to a solution of $2(1.7 \mathrm{mg}$, $3.3 \mu \mathrm{mol})$ in dry pyridine $(1 \mathrm{ml})$ at room temperature. After $18 \mathrm{~h}$, the reaction mixture was concentrated to dryness and purified by silica-gel column chromatography $(n$-hexane/EtOAc $=1: 0-1: 1)$, to yield $3(1.6 \mathrm{mg}, 42 \%):{ }^{1} \mathrm{H}$ NMR $\left(500 \mathrm{MHz}, \mathrm{CDCl}_{3}\right) \delta 0.87(3 \mathrm{H}, \mathrm{d}, J=7.0 \mathrm{~Hz}, \mathrm{H}-26), 0.91(3 \mathrm{H}, \mathrm{t}$, $J=7.4 \mathrm{~Hz}, \mathrm{H}-30), 1.04$ (3 H, s, H-27), 1.34 ( $1 \mathrm{H}$, ddd, $J=12.0,12.0,12.0 \mathrm{~Hz}$ H-6 $\alpha), 1.73$ (3 H, s, H-28), 1.79 ( $1 \mathrm{H}, \mathrm{m}, \mathrm{H}-14), 1.82$ ( $1 \mathrm{H}, \mathrm{m}, \mathrm{H}-5), 1.82(1 \mathrm{H}$, m, H-6ß), 1.85 (1 H, m, H-14), 1.85 (1 H, m, H-17a), 2.20 (1 H, m, H-10), 2.40 (dd, $J=14.3,11.5 \mathrm{~Hz}, \mathrm{H}-17 \mathrm{~b}), 2.78$ ( $1 \mathrm{H}, \mathrm{m}, \mathrm{H}-8), 2.83$ ( $1 \mathrm{H}, \mathrm{dd}, J=5.0$, $5.0 \mathrm{~Hz}, \mathrm{H}-13), 4.87$ (1 H, s, H-19), 4.91 ( $1 \mathrm{H}, \mathrm{dd}, J=11.5,4.7 \mathrm{~Hz}, \mathrm{H}-9), 5.05$ $(1 \mathrm{H}, \mathrm{dd}, J=14.8,11.5 \mathrm{~Hz}, \mathrm{H}-16), 5.10(1 \mathrm{H}, \mathrm{d}, J=10.0 \mathrm{~Hz}, \mathrm{H}-11), 5.28(1 \mathrm{H}$, m, H-15), 5.30 ( $1 \mathrm{H}, \mathrm{m}, \mathrm{H}-7), 5.48$ ( $1 \mathrm{H}$, ddd, $J=10.0,5.0,2.4 \mathrm{~Hz}, \mathrm{H}-12)$; HR ESITOFMS m/z $965.3652[\mathrm{M}+\mathrm{Na}]^{+}$(calcd for $\mathrm{C}_{51} \mathrm{H}_{56} \mathrm{~F}_{6} \mathrm{O}_{10} \mathrm{Na}, 965.3670$ ).

\section{Bis-(S)-MTPA ester of 2 (4)}

In the same manner as described for $3,4(1.3 \mathrm{mg})$ was prepared from $1.7 \mathrm{mg}$ of 2: ${ }^{1} \mathrm{H}$ NMR $\left(500 \mathrm{MHz}, \mathrm{CDCl}_{3}\right) \delta 0.73(3 \mathrm{H}, \mathrm{d}, J=7.0 \mathrm{~Hz}, \mathrm{H}-26), 0.91(3 \mathrm{H}, \mathrm{t}$, $J=7.4 \mathrm{~Hz}, \mathrm{H}-30), 1.05(3 \mathrm{H}, \mathrm{s}, \mathrm{H}-27), 1.25(1 \mathrm{H}$, ddd, $J=11.7,11.7,11.7 \mathrm{~Hz}$,

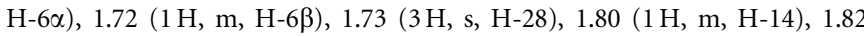
(1 H, m, H-5), 1.85 (1 H, m, H-14), 1.86 (1 H, m, H-17a), 2.20 (1 H, m, H-10), 2.41 (dd, $J=14.0,11.7 \mathrm{~Hz}, \mathrm{H}-17 \mathrm{~b}), 2.79(1 \mathrm{H}, \mathrm{m}, \mathrm{H}-8), 2.85(1 \mathrm{H}, \mathrm{dd}, J=5.0$, $5.0 \mathrm{~Hz}, \mathrm{H}-13), 4.86$ ( $1 \mathrm{H}$, dd, $J=11.6,4.7 \mathrm{~Hz}, \mathrm{H}-9), 4.88$ (1 H, s, H-19), 5.06 $(1 \mathrm{H}, \mathrm{dd}, J=14.9,11.7 \mathrm{~Hz}, \mathrm{H}-16), 5.28$ (1 H, m, H-7), $5.29(1 \mathrm{H}, \mathrm{m}, \mathrm{H}-15)$, $5.32(1 \mathrm{H}, \mathrm{d}, J=10.0 \mathrm{~Hz}, \mathrm{H}-11), 5.56(1 \mathrm{H}$, ddd, $J=10.0,5.0,2.4 \mathrm{~Hz}, \mathrm{H}-12)$; HR-ESITOFMS m/z $965.3679[\mathrm{M}+\mathrm{Na}]^{+}$(calcd for $\mathrm{C}_{51} \mathrm{H}_{56} \mathrm{~F}_{6} \mathrm{O}_{10} \mathrm{Na}$, 965.3670).

\section{Biological assays}

Antimicrobial assay ${ }^{16}$ and cytotoxic assay ${ }^{17}$ were carried out according to the procedures previously described.

\section{ACKNOWLEDGEMENTS}

We acknowledge Dr T Okuda and Ms Y Sudoh at Tamagawa University for assistance with antimicrobial assay.

1 Butler, M. S. Natural products to drugs: natural product-derived compounds in clinical trials. Nat. Prod. Rep. 25, 475-516 (2008).

2 Bérdy, J. Bioactive microbial metabolites. J. Antibiot. 58, 1-26 (2005).

3 Smith, A. L. \& Nicolaou, K. C. The enediyne antibiotics. J. Med. Chem. 39, 2103-2117 (1996)

4 Walsh, T. J. \& Giri, N. Pradimicins: a novel class of broad-spectrum antifungal compounds. Eur. J. Clin. Microbiol. Infect. Dis. 16, 93-97 (1997).

5 Dirlam, J. P. et al. CP-84,657, a potent polyether anticoccidial related to portmicin and produced by Actinomadura sp. J. Antibiot. 43, 668-679 (1990).

6 Igarashi, Y. et al. Brartemicin, an inhibitor of tumor cell invasion from the actinomycete Nonomuraea sp. J. Nat. Prod 72, 980-982 (2009).

7 Igarashi, Y. et al. Maklamicin, an antibacterial polyketide from an endophytic Micromonospora sp. J. Nat. Prod. 74, 670-674 (2011).

8 Matsumori, N., Kaneno, D., Murata, M., Nakamura, H. \& Tachibana, K. Stereochemical determination of acyclic structures based on carbon-proton spin-coupling constants. A 
method of configuration analysis for natural products. J. Org. Chem. 64, 866-876 (1999).

9 Furihata, K. \& Seto, H. J-Resolved HMBC, a new NMR technique for measuring heteronuclear long-range coupling constants. Tetrahedron Lett. 40, 6271-6275 (1999).

10 Furihata, K., Tashiro, M. \& Seto, H. Selective J-resolved HMBC, an efficient method for measuring heteronuclear long-range coupling constants. Magn. Reson. Chem. 47, 814-818 (2009).

11 Ohtani, I., Kusumi, T., Kashman, Y. \& Kakisawa, H. High-field FT NMR application of Mosher's method. The absolute configurations of marine terpenoids. J. Am. Chem. Soc. 113, 4092-4096 (1991).

12 Konno, K., Fujishima, T., Liu, Z. \& Takayama, H. Determination of absolute configuration of 1,3 -diols by the modified Mosher's method using their di-MTPA esters. Chirality 13, 72-80 (2002).
13 Momose, I. et al. Decatromicins $A$ and $B$, new antibiotics produced by Actinomadura sp. MK73-NF4. II. Structure determination. J. Antibiot. 52, 787-796 (1999).

14 Park, H-R., Chijiwa, S., Furihata, K., Hayakawa, Y. \& Shin-ya, K. Relative and absolute configuration of versipelostatin, a down-regulator of molecular chaperone GRP78 expression. Org. Lett. 9, 1457-1460 (2007).

15 Mallams, A. K., Puar, M. S., Rossman, R. R., McPhail, A. T. \& Macfarlane, R. D. Kijanimicin. 2. Structure and absolute stereochemistry of kijanimicin. J. Am. Chem. Soc. 103, 3940-3943 (1981).

16 Igarashi, Y. et al. Abyssomicin I, a modified polycyclic polyketide from Streptomyces sp. CHI39. J. Nat. Prod. 73, 1943-1946 (2010).

17 Fukuda, T. et al. Marianins A and B, prenylated phenylpropanoids from Mariannaea camptospora. J. Nat. Prod. 74, 1327-1330 (2011). 